Jurnal Abdidas Volume 2 Nomor 5 Tahun 2021 Halaman 1043-1048

JURNAL ABDIDAS

http://abdidas.org/index.php/abdidas

\title{
Sosialisasi Pakan Ternak Larva Lalat Black Soldier Fly (BSF)
}

\author{
Masni Veronika Situmorang ${ }^{1 凶}$, Binsar Tison Gultom ${ }^{2}$, Gunaria Siagian ${ }^{3}$, Lois Oinike Tambunan ${ }^{4}$ \\ Universitas HKBP Nommensen Pematangsiantar, Indonesia ${ }^{1,2,3,4}$ \\ Email : masniveronika@gmail.com ${ }^{1}$, binsartisongultom@gmail.com ${ }^{2}$, gunariasiagian5@gmail.com ${ }^{3}$, \\ loisoiniketambunan@gmail.com ${ }^{4}$
}

\begin{abstract}
Abstrak
Meningkatnya harga sumber protein dan adanya ancaman ketahanan pakan ternak, tekanan lingkungan, dan meningkatnya permintaan protein di pasar menyebabkan harga protein berbasis hewan semakin mahal. Padahal pakan merupakan salah satu hal yang sangat penting dalam peternakan. Tujuan diadakannya pengabdian ini adalah untuk mensosialisasikan pakan ternak larva lalat Black Soldier Fly (BSF) sebagai solusi untuk pakan ternak. Metode pelaksanaannya adalah dengan memperkenalkan lalat Black Soldier Fly (BSF), cara beternak lalat BSF, dan penggunaan maggot sebagai pakan ternak. Diadakan pula evaluasi untuk mengukur keberhasilan dari kegiatan pengabdian ini. Hasilnya menunjukkan bahwa masyarakat di Kelurahan Pardamean antusias dalam mengikuti kegiatan tersebut. Pelaksanaan sosialisasi ini memberikan pengetahuan dan keterampilan dalam menekan biaya pembelian pakan ternak sekaligus mengurangi sampah organik yang dihasilkan rumah tangga.
\end{abstract}

Kata kunci : black soldier fly, maggot, pakan ternak

\section{Abstract}

The increasing price of protein sources and the threat of animal feed security, environmental pressures, and increasing demand for protein in the market have caused the price of animal-based protein to become increasingly expensive. Though feed is one of the most important things in animal husbandry. The purpose of this service is to socialize Black Soldier Fly (BSF) larvae animal feed as a solution for animal feed. The implementation method is to introduce the Black Soldier Fly (BSF), how to raise BSF flies, and the use of maggot as animal feed. An evaluation was also held to measure the success of this service activity. The results show that the people in Pardamean Village are enthusiastic in participating in these activities. The implementation of this socialization provides knowledge and skills in reducing the cost of purchasing animal feed while reducing organic waste generated by households.

Keywords: black soldier fly, maggot, animal feed

Copyright (c) 2021 Masni Veronika Situmorang, Binsar Tison Gultom, Gunaria Siagian, Lois Oinike Tambunan

$\triangle$ Corresponding author

Address : Universitas HKBP Nommensen Pematangsiantar

ISSN 2721- 9224 (Media Cetak)

Email : masniveronika@gmail.com

DOI : https://doi.org/10.31004/abdidas.v2i5.423

ISSN 2721- 9216 (Media Online) 
1044 Sosialisasi Pakan Ternak Larva Lalat Black Soldier Fly (BSF) - Masni Veronika Situmorang, Binsar Tison Gultom, Gunaria Siagian, Lois Oinike Tambunan

DOI: https://doi.org/10.31004/abdidas.v2i5.423

\section{PENDAHULUAN}

Pakan merupakan komponen penting dalam budidaya ikan dan ayam untuk menunjang pertumbuhan serta kelangsungan hidup ikan budidaya dan ayam ternak. Pakan komersial saat ini memiliki harga yang tinggi sehingga pelaku usaha budidaya ikan tawar dapat menghabiskan biaya mencapai $75 \%$ dari total biaya yang dibutuhkan untuk budidaya (Wardhana, 2016). Mahalnya harga pakan mengakibatkan keuntungan yang diperoleh pembudidaya tidak maksimal bahkan dapat merugi. Pemberian pakan juga harus memperhatikan kualitas dan kuantitas, sehingga sesuai dengan kebutuhan gizi yang diperlukan oleh ikan. Pakan yang berkualitas memiki kandungan nutrisi yang lengkap, mudah dicerna oleh ikan dan tidak mengandung zat-zat berbahaya bagi ikan.

Black Soldier Fly (BSF), lalat tentara hitam (Hermetia illucens, Diptera: Stratiomydae) adalah salah satu insekta yang mulai banyak dipelajari karakteristiknya dan kandungan nutriennya untuk dijadikan pakan ternak. Pemanfaatan larva BSF sebagai pakan ternak memiliki keuntungan secara langsung maupun tidak langsung. (RACHMAWATI et al., 2015) menyatakan bahwa larva yang lebih besar (prepupa) sangat ideal digunakan untuk campuran pakan atau bahan baku pelet karena mampu memenuhi kuantitas produksi. Larva muda lebih sesuai diberikan untuk pakan ikan secara langsung, karena bentuknya yang kecil sesuai dengan ukuran mulut ikan.

Larva BSF mampu mengurai limbah organik termasuk limbah kotoran ternak secara efektif karena larva tersebut termasuk golongan detrivora, yaitu organisme pemakan tumbuhan dan hewan yang telah mengalami pembusukan. Dibandingkan dengan larva dari keluarga lalat Muscidae dan Calliphoridae, larva ini tidak menimbulkan bau yang menyengat dalam proses mengurai limbah organik sehingga dapat diproduksi di rumah atau pemukiman. Pernyataan ini sesuai dengan penelitian yang dilakukan oleh (Supriyatna et al., 2016) yang menunjukkan adanya penurunan senyawa volatil pada media yang diberi larva BSF berdasarkan pengamatan di laboratorium. (Diener et al., 2011) juga menyatakan bahwa larva BSF mampu mengurangi hingga $68 \%$ sampah perkotaan, $50 \%$ untuk kotoran ayam, 39\% untuk kotoran babi serta 25\% untuk campuran kotoran ayam dan sapi. (zakova M, 2013) menyatakan larva BSF mampu mengurai sampah tanaman hingga 66,53\%. Berbagai insekta yang dapat dikembangkan sebagai pakan, kandungan protein larva BSF cukup tinggi yaitu 40-50\%, dengan kandungan lemak berkisar 29$32 \%$.

Kondisi iklim tropis Indonesia sangat ideal untuk budidaya BSF. Ditinjau dari segi budidaya, BSF sangat mudah untuk dikembangkan dalam skala produksi massal dan tidak memerlukan peralatan yang khusus. Tahap akhir larva (prepupa) dapat bermigrasi sendiri dari media tumbuhnya sehingga memudahkan untuk dipanen. Selain itu, lalat ini bukan merupakan lalat hama dan tidak dijumpai pada pemukiman yang padat penduduk sehingga relatif aman jika dilihat dari segi kesehatan manusia.

Berdasarkan permasalahan yang telah diuraikan di atas, maka tujuan dari pengabdian ini 
1045 Sosialisasi Pakan Ternak Larva Lalat Black Soldier Fly (BSF) - Masni Veronika Situmorang, Binsar Tison Gultom, Gunaria Siagian, Lois Oinike Tambunan

DOI: https://doi.org/10.31004/abdidas.v2i5.423

adalah untuk mengadakan sosialisasi pakan ternak lalat Black Soldier Fly (BSF).

\section{METODE}

Kegiatan Pengabdian kepada Masyarakat (PkM) dilaksanakan selama 2 hari yaitu pada 1415 Januari 2021 di Kelurahan Pardamean, Kecamatan Siantar Marihat dengan sasaran pelaksanaannya adalah masyarakat Kelurahan Pardamean. Pelatihan berisi tentang sosialisasi pakan ternak larva lalat Black Soldier Fly (BSF). Tahap rencana kegiatan pengabdian kepada masyarakat ini terdiri atas:

\section{Tahap Persiapan}

Tim PkM melakukan wawancara dengan Lurah Pardamean. Berdasarkan hasil wawancara diperoleh informasi bahwa beberapa dari masyarakat yang ada di kelurahan tersebut memiliki pekerjaan sebagai peternak unggas. Selama ini masyarakat memberikan pakan ternak mereka berupa sisa makanan dan pelet. Sisa makanan terkadang tidak mencukupi kebutuhan ternak, sementara harga pelet terbilang cukup mahal. Berdasarkan informasi tersebut Tim berdiskusi untuk mencari cara penyelesaian permasalahan tersebut. Dari hasil diskusi Tim berencana untuk mengadakan sosialisasi larva lalat BSF yang digunakan sebagai pakan ternak.

\section{Tahap Pelaksanaan}

Pada tahap pelaksanaan tim bergerak ke kantor Kelurahan Pardamean untuk mengadakan sosialisasi. Peserta dalam kegiatan sosialisasi ini adalah Lurah Pardamean, pegawai kelurahan, dan masyarakat Kelurahan Pardamean. Kegiatan ini diawali dengan kata sambutan dari Lurah Pardamean, kemudian dilanjutkan dengan penyampaian materi mengenai pakan ternak lalat BSF, manfaat lalat BSF, beserta keunggulan dari penggunaan larva lalat tersebut sebagai pakan ternak. Masing-masing dosen sebagai tim PkM bertugas untuk membantu peserta selama kegiatan berlangsung.

\section{Tahap Evaluasi}

Pada tahap ini tim PkM menyebarkan angket untuk mengukur pemahaman masyarakat setelah pelatihan tersebut dilaksanakan. Angket terdiri dari 4 indikator yang terdiri dari penyampaian materi, pemanfaatan larva BSF, manfaat kegiatan PkM, dan Umpan balik kegiatan PkM. Angket menggunakan skala Likert dengan ketentuan SS (Sangat Setuju), S (Setuju), TS (Tidak Setuju), dan STS (Sangat Tidak Setuju). Prosedur kegiatan Pengabdian kepada Masyarakat adalah sebagai berikut

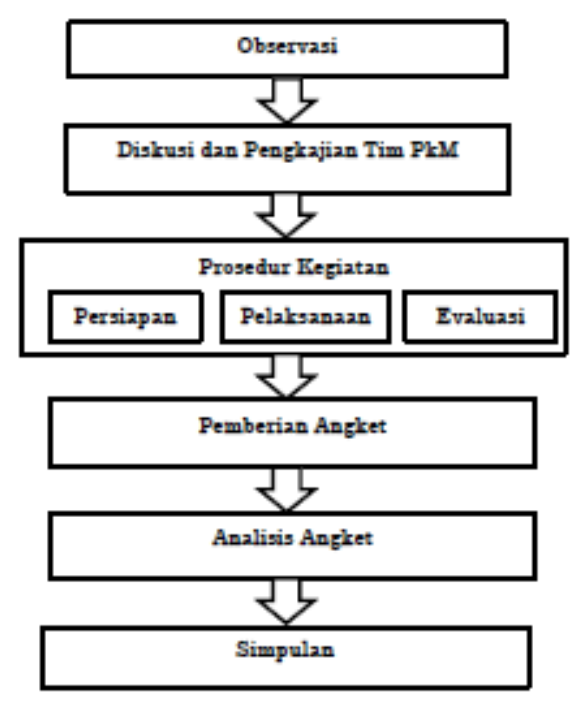

Gambar 1. Prosedur Kegiatan PkM 
1046 Sosialisasi Pakan Ternak Larva Lalat Black Soldier Fly (BSF) - Masni Veronika Situmorang, Binsar Tison Gultom, Gunaria Siagian, Lois Oinike Tambunan

DOI: https://doi.org/10.31004/abdidas.v2i5.423

\section{HASIL DAN PEMBAHASAN}

Pada tahap persiapan, tim PkM melakukan observasi dengan mewawancarai Lurah Pardamean untuk mengetahui mata pencaharian masyarakat di kelurahan tersebut. Diketahui bahwa beberapa masyarakat di kelurahan tersebut memiliki mata pencaharian sebagai peternak unggas. Selama ini masyarakat memberikan sisa makanan dan pelet sebagai pakan ternak. Sisa makanan susah untuk diperoleh, sementara harga pelet cenderung mahal.

Kemudian dilakukanlah sosialisasi penggunaan larva lalat Black Soldier Fly (BSF) kepada masyarakat. Kegiatan ini berjalan dengan lancar karena materi yang disampaikan oleh nara sumber (dosen) bermanfaat bagi masyarakat. Sosialisasi ini mencakup pengenalan tentang lalat Black Soldier Fly (BSF), cara beternak lalat BSF, pemanfaatan larva lalat BSF sebagai pakan ternak.

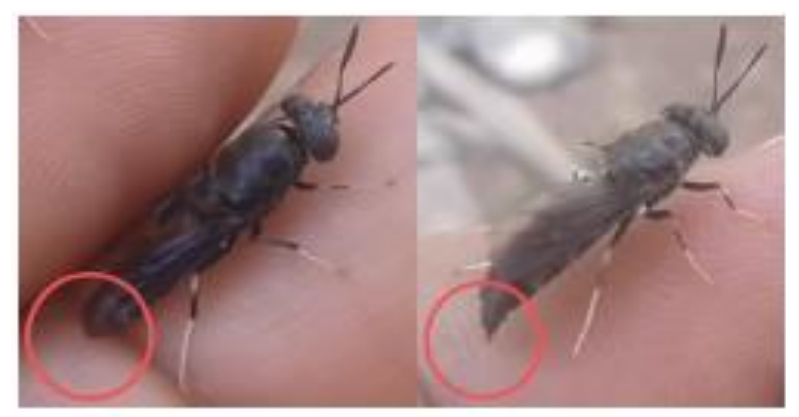

Gambar 2. Lalat BSF Jantan (kiri) dan Betina (kanan)

Dijelaskan pula fasilitas yang diperlukan dalam membudidayakan lalat BSF, antara lain:

1. Kandang : Tempat lalat dewasa hidup

Syarat kandang yang baik untuk pertumbuhan lalat BSF :

- Kelembapan $>75 \%$

- Suhu $28-30^{\circ} \mathrm{C}$
- Mendapatkan sinar matahari

- Tersedia tempat bertelur (kayu)

2. Bioreaktor: Tempat larva memproses limbah organik.

Syarat bioreaktor: :

- Kadar air pakan 40-70\%

- Suhu 25 - $35^{\circ} \mathrm{C}$

- Ketinggian substrat $5 \mathrm{~cm}$

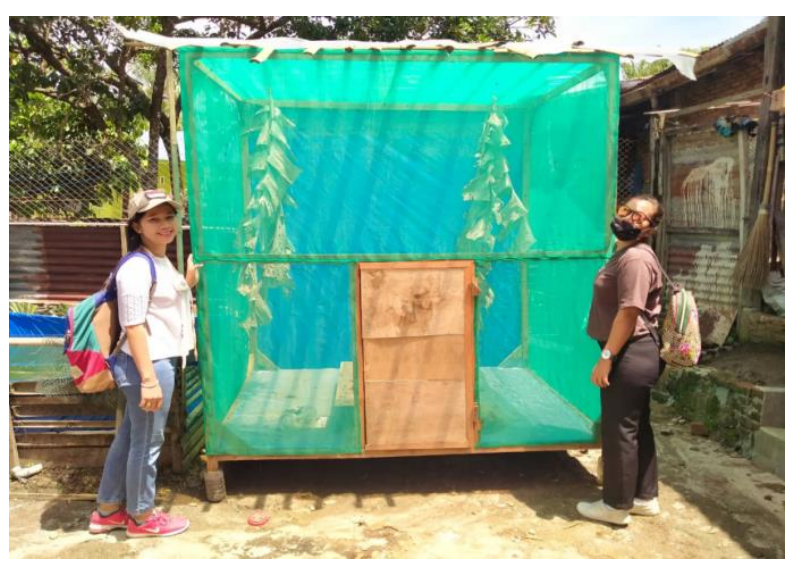

Gambar 3. Kandang Lalat BSF

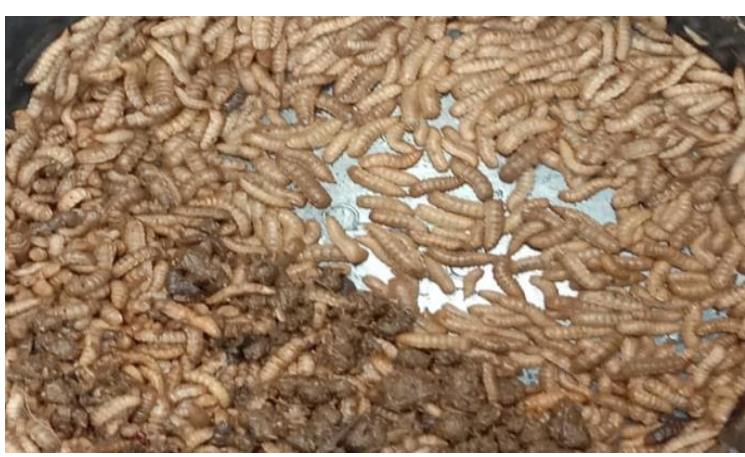

Gambar 4. Larva lalat BSF

Maggot yang merupakan larva lalat Black Soldier Fly (BSF) memang sangat istimewa dibandingkan bahan baku pakan alternatif lainnya karena mengandung nutrien yang lengkap untuk pakan ternak dan kualitas yang baik. Maggot mengandung protein yang tinggi. Selain itu, Maggot bisa diproduksi dalam waktu singkat dan 
1047 Sosialisasi Pakan Ternak Larva Lalat Black Soldier Fly (BSF) - Masni Veronika Situmorang, Binsar Tison Gultom, Gunaria Siagian, Lois Oinike Tambunan

DOI: https://doi.org/10.31004/abdidas.v2i5.423

berkesinambungan dengan jumlah yang cukup untuk memenuhi kebutuhan pakan.

Keunggulan lainnya, yaitu masyarakat mudah mengadopsi teknologi produksi Maggot. Kemudian, dalam prosesnya Maggot juga bisa diproduksi menjadi tepung (mag meal), sehingga bisa menekan biaya produksi pakan. Media utama dalam produksi maggot ini adalah sampah organik. Maka dengan digunakannya sampah organik ini dapat mengurangi produksi limbah rumah tangga.

Masyarakat mendengarkan penjelasan dari nara sumber dengan seksama dan tekun. Dan mereka langsung ingin mempraktekkannya dengan mengganti sumber pakan ternak mereka dengan maggot (larva lalat BSF) tersebut.

Penelitian yang dilakukan oleh (FAHMI, 2015) yang mengatakan bahwa pertumbuhan ikan gurame yang diberi pakan maggot yang berasal dari media PKM, limbah pasar dan limbah ikan menunjukkan pertumbuhan yang lebih baik. Studi lain juga diuji pada burung puyuh (Coturnix coturnix japonica) dengan cara mengganti tepung ikan dengan tepung BSF, termasuk melakukan beberapa kombinasi tepung ikan dan tepung BSF dengan persentase yang berbeda (Suparman et al., 2020) Substitusi 50-75\% tepung ikan dengan tepung BSF memberikan respon yang positif terhadap produksi dan bobot telur puyuh, tingkat konsumsi pakan serta konversi pakan. (Wardhana, 2016) menyatakan bahwa sumber pakan BSF mengandung protein tinggi (40-50\%) sehingga dapat digunakan sebagai sumber protein alternatif untuk pakan ternak.

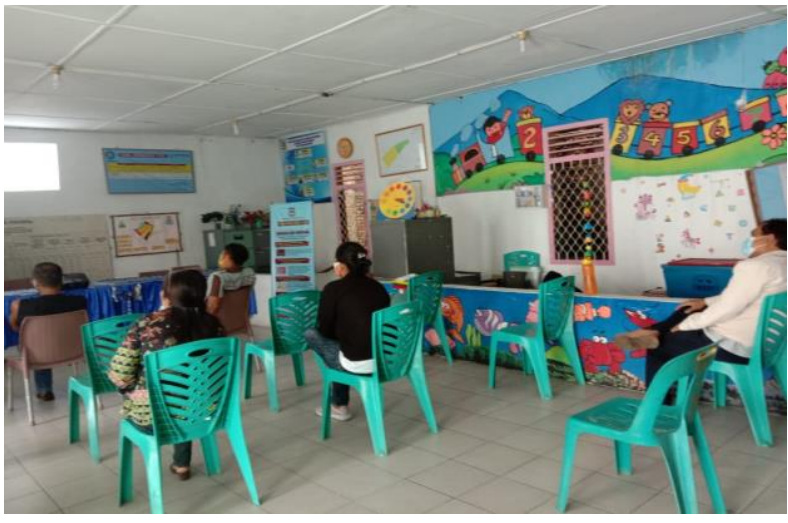

Gambar 5. Masyarakat mendengarkan penjelasan nara sumber

Masyarakat dengan antusias menyambut penjelasan tersebut. Namun kendala yang mereka hadapi adalah bahan baku untuk larva lalat BSF berupa pupa. Oleh karena itu para nara sumber (dosen) bersedia untuk memfasilitasi penyediaan bahan tersebut. Bahkan bila diperlukan dosen bersedia untuk memandu secara langsung pengembangbiakan dari lalat BSF tersebut.

Pada tahap evaluasi dilakukan pemberian angket. Pemberian angker ini bertujuan untu melihat sejauhmana keberhasilan proses pelaksanaan PkM. Hasil angket tersebut dapat ditunjukkan dalam gambar berikut.

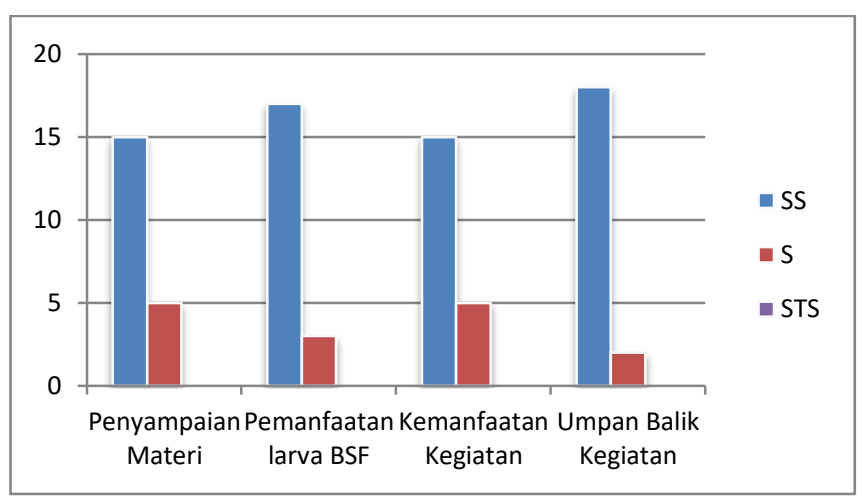

Gambar 6. Hasil Angket 
1048 Sosialisasi Pakan Ternak Larva Lalat Black Soldier Fly (BSF) - Masni Veronika Situmorang, Binsar Tison Gultom, Gunaria Siagian, Lois Oinike Tambunan

DOI: https://doi.org/10.31004/abdidas.v2i5.423

Berdasarkan grafik diatas, $75 \%$ peserta menyatakan sangat setuju pada indikator penyampaian materi dan $25 \%$ peserta yang menyatakan setuju. Pada indikator kedua yaitu pemanfaatan larva BSF menyatakan $85 \%$ sangat setuju dan $15 \%$ menyatakan setuju. Untuk indikator ketiga yaitu kemanfaatan kegiatan, 75\% menyatakan sangat setuju dan $25 \%$ menyatakan setuju. Untuk indikator terakhir yaitu indikator keempat yaitu umpan balik kegiatan 90\% menyatakan sangat setuju dan $10 \%$ menyatakan setuju. Hal ini menunjukkan bahwa masyarakat begitu antusias dan bersemangat dalam mengikuti kegiatan tersebut. Pelaksanaan sosialisasi ini juga membantu masyarakat dalam mengurangi penggunaan pelet dan menggunakan larva lalat BSF sebagai pakan organik untuk ternak mereka.

\section{SIMPULAN}

Berdasarkan kegiatan PkM yang telah dilakukan dapat disimpulkan bahwa masyarakat Kelurahan Pardamean telah memperoleh pengetahuan dan keterampilan dalam penggunaan larva lalat BSF sebagai pakan ternak. Melalui sosialisasi ini masyarakat dapat menekan biaya pembelian pakan ternak sekaligus mengurangi produksi limbah rumah tangga.

\section{UCAPAN TERIMAKASIH}

Tim pengabdian kepada masyarakat mengucapkan terima kasih kepada Bapak Edo Putra Haro Munte, S.STP., Lurah Pardamean yang telah memfasilitasi kegiatan pengabdian ini sehingga terlaksana dengan baik.

\section{DAFTAR PUSTAKA}

Diener, S., Zurbrugg, C., Roa Gutiérrez, F., Nguyen, H. D., Morel, A., Koottatep, T., \& Tockner, K. (2011). Black soldier fly larvae for organic waste treatment - prospects and constraints. WasteSafe 2011 2nd International Conference on Solid Waste Management in Developing Countries 1315 February 2011 Khulna Bangladesh, 52(February), 978-984.

FAHMI, M. R. (2015). Optimalisasi proses biokonversi dengan menggunakan mini-larva Hermetia illucens untuk memenuhi kebutuhan pakan ikan. 1(Fao 2004), 139144.

https://doi.org/10.13057/psnmbi/m010124

RACHMAWATI, R., BUCHORI, D., HIDAYAT, P., HEM, S., \& FAHMI, M. R. (2015). Perkembangan dan Kandungan Nutrisi Larva Hermetia illucens (Linnaeus) (Diptera: Stratiomyidae) pada Bungkil Kelapa Sawit. Jurnal Entomologi Indonesia, 7(1), 28. https://doi.org/10.5994/jei.7.1.28

Suparman, S., Purwanti, S., \& Nahariah, N. (2020). Substitution of fish meal with black soldier fly larvae (Hermetia illucens) meal to eggs production and physical quality of quail (Coturnix coturnix japonica) eggs. IOP Conference Series: Earth and Environmental Science, 492(1). https://doi.org/10.1088/17551315/492/1/012014

Supriyatna, A., Manurung, R., Esyanti, R. R., \& Putra, R. E. (2016). Growth of black soldier larvae fed on cassava peel wastes, An agriculture waste. $\sim 161 \sim$ Journal of Entomology and Zoology Studies, 4(6), 161165.

Wardhana, A. (2016). Black Soldier Fly (Hermetia illucens) as an Alternative Protein Source for Animal Feed. WARTAZOA. Indonesian Bulletin of Animal and Veterinary Sciences, 26(2), 069-078. https://doi.org/10.14334/wartazoa.v26i2.1218

zakova M, B. M. (2013). Comparison of field and lab application of Hermetia illucens larvae. 